\author{
Bartosz Kwiatkowski \\ Jagiellonian University in Kraków, Poland \\ ORCID: 0000-0002-1761-3183 \\ bartosz.kwiatkowski@doctoral.uj.edu.pl
}

\title{
Legal Act as the Subject of Mythologization: Remarks on the Reception of the JUST Act of 2017 in Poland
}

\author{
Akt prawny jako przedmiot mitologizacji - uwagi na temat recepcji \\ tzw. ustawy 447 na gruncie polskim
}

\begin{abstract}
The article presents a legal act as a potential subject of mythologization. The tools derived from the studies on political myth were used to describe a phenomenon that strictly belongs to the political and legal reality - the American JUST Act of 2017, which in recent years has caused many controversies in Polish public debate. While using the theoretical methods of the most notable researchers of the political myth, such as R. Barthes or E. Cassirer, it has been shown that legal acts, as well as their reception and interpretation, are not always based on rational forms of cognition. They can also be affected by a political myth and a mythical form of cognition, which is depicted in this study by means of methodology implemented from the studies on political myth. The article formulates interesting comments that may be useful for a better understanding of the phenomena on the border of Polish jurisprudence, political science and mythology.
\end{abstract}

Keywords: political myth; legal act; the JUST Act; mythologization

\section{INTRODUCTION}

The phenomenon of myth (including the political myth which is especially interesting for those who specialize in the history of political thought), is a subject that can be studied by scientist that come from many different disciplines and who can

CORRESPONDENCE ADDRESS: Bartosz Kwiatkowski, PhD Student, Jagiellonian University in Kraków, Faculty of Law and Administration, Gołębia 24, 31-007 Kraków, Poland. 
therefore present many different approaches: psychological, political, sociological, historical, or the one that reflects the position of literature or religious studies. While the topic of myth is mainly presented in the context of political or socio-cultural reality, one may struggle to find in today's studies of myth an approach that presents the myth's connections with the reality of law.

When one decides to undertake the scientific studies of political myth, a crucial problem determining the whole character of that scientific work is defining its subject. One must notice that the subject which is searched for in this case, consists of many different forms of myth's manifestations or expressions of mythical content, throughout which mythically characterized signs can be read off. Myth, in the context of all the theories presented in this paper, is not understood as a tale about legendary heroic deeds. Rather than that, it is considered to be a way of thinking that leads to making sense of the reality that surrounds us. This way of understanding the myth corresponds with the attitude presented by the majority of well-known scientists who studied the subject. For example, M. Napiórkowski, who studies myths in today's vernacular culture, notices that "the myth asks us about the sense, while it is a practice of imposing the meaning itself". ${ }^{1}$ On the other hand, M. Eliade, a specialist in explaining myths from the perspective of the history of religion, was emphasizing that he is interested in the concept of the myth understood as a tool used to create patterns of behavior or to give the meaning and value to people's existence. ${ }^{2}$ For R. Barthes, who was describing myths from the perspective of semiology, myths were "a form, a way of imposing a meaning". ${ }^{3}$ There is no need to cite other attempts to define the concept of myth by different scientists who worked on this subject. Those that are quoted above are enough to justify a statement, that at least the character and the functions of myth are not controversial in modern studies of myth, regarding many different scientific perspectives.

Since a basic understanding of what the myth is seems to be non-controversial, it is necessary to address the consequence of a great importance (especially for those who study the history of political thought) that is created by this way of describing the myth. Because of the fact that the myth is considered to be a specific form of transmitting the mythical content one must ask where should we look for the means of this mythical transmission? In this case, the opinions of the scientists that were cited above are going to be slightly different. For example, M. Eliade would say that using the myth is an activity which is typical for primitive communities and that nowadays, even if the mythical way of thinking did not completely disappear, it is "reduced to the realm of second-tiered or even irresponsible social actions". ${ }^{4} \mathrm{On}$

\footnotetext{
M. Napiórkowski, Mitologia współczesna, Warszawa 2018, p. 10.

M. Eliade, Aspekty mitu, Warszawa 1998, p. 8.

3 R. Barthes, Mit i znak, Warszawa 1970, p. 25.

${ }^{4}$ M. Eliade, Mity, sny, misteria, Warszawa 1999, p. 32.
} 
the other hand, E. Cassirer, a founder of the neo-Kantian theory of myth, would say the opposite - that the mythical way of thinking is a major factor even in modern political systems and that it is impossible to find any major culture in the history of mankind that would not be rich in mythical elements. ${ }^{5}$ Where then, in today's world, can we find a source of knowledge about myths which function in modern reality? Is their role today limited only to interesting, but politically less important socio-cultural aspects, and as a consequence of that, is there a researcher who works in the area of political and legal thought limited in his attempts to find any mythical content in the instruments of political and legal reality?

\section{MATERIALS AND METHOD}

There is definitely some truth in the statement that the mythical way of thinking has never disappeared in modern societies. Obviously, these days a major role is played by rational and scientific cognition. However, this does not mean that the mythical way of thinking does not exist anymore, it only means that the proportions in the use of different methods of cognition have changed while compared to the primitive communities. Modern mythologies, as M. Napiórkowski notices, "are born at the crossroads of an amazing complexity of the modern world and the individual cognition". ${ }^{6}$ According to this author, this statement must lead to a conclusion that the place where expressions of the mythical content may appear is not only the popular culture and everyday life of modern societies, but also those products of human activity, which in the world of a very advanced specialization and complexity that surrounds us, cannot be understood by the majority of the people. Without any doubt, this group also includes the political and legal activity.

This article is an attempt to describe those means of mythical content's transmission that belong to the political and legal reality by using various theoretical tools, borrowed from the works of the theorists that were previously presented. The subject of the analysis are the elements of mythologization that occurred at the reception of the JUST Act of 2017 - a legal act that was passed by the United States Congress. Its political meaning shortly became very controversial in Polish public debate. According to the author, it happened precisely because of the extremely strong mythical content in the public discussion that arose around the legal act, which despite the common opinion is a phenomenon that can be interpreted not only by using the rational means of understanding.

\footnotetext{
${ }^{5}$ E. Cassirer, Mit państwa, Warszawa 2006, pp. 13-14.

${ }^{6}$ M. Napiórkowski, op. cit., p. 38.
} 


\section{WHAT IS THE JUST ACT OF 2017?}

Despite the fact that the legal analysis of the JUST Act is not the main aim of this article, it is necessary for the following analysis to at least briefly discuss its general character. What in Polish debate is called ustawa 477 is in fact the Justice for Uncompensated Survivors Today Act of 2017 (or JUST Act of 2017). ${ }^{7}$ The Act is legislation signed on 9 May 2018, after being passed both in the Senate and the House of Representatives. The content of the Act is easily accessible through official databases. Its little volume - about a page and a half - allows every potential reader to become easily informed about the source of the whole debate that was the result of the bill's passing. ${ }^{8}$

The main and, in fact, the only aim of the legislation is to create an obligation for the Department of State to present a special one-time report to Congress. ${ }^{9}$ The deadline to present the report was set to be 18 months after the legislation became law. The report has to present to Congress the steps and actions that were taken by the states that signed the non-binding Terezin Declaration of 2009 to fulfill its provisions. One of the signatories of the declaration is also the Republic of Poland, which like other 46 countries declared to take steps to fulfill its provisions almost 10 years before the JUST Act was passed.

The report's concern is to describe how the provisions of the Terezin Declaration are fulfilled by its signatories, with special consideration of those provisions that are directly mentioned in the JUST Act. These are the laws and policies of covered countries that refer to: the return of (or restitution for if the return is not possible) of the wrongfully seized or transferred Holocaust era assets to its rightful owners, ${ }^{10}$ including religious organizations; in case of heirless property - the compensation that is understood as supporting those Holocaust survivors who happened to be in tough financial situation, supporting Holocaust education and other purposes; the extent to which such laws and policies are practically enforced through administrative and judicial processes; the extent to which the aims and goals of the declaration are practically enforced when it comes to claims of United States citizens Holocaust survivors or the claims of their families.

7 The name ustawa 447 which became the most popular description of the bill in Poland refers to the number that was assigned to the legislation during the proceedings in the Senate -447 .

8 Justice for Uncompensated Survivors Today (JUST) Act of 2017, www.congress.gov/115/ plaws/publ171/PLAW-115publ171.pdf [access: 27.01.2020].

9 According to the JUST Act the report should be presented to the foreign affairs and budget committees of both the Senate and the House of Representatives.

${ }_{10}$ According to the JUST Act the property that was wrongfully seized or transferred is the property that was nationalized, confiscated, expropriated or was the object of forced sales or transfers and sales or transfers under duress during the Holocaust era or the period of Communist rule of a covered country. 
It also has to be mentioned, that in the text of the Terezin Declaration, to which the JUST Act directly refers by deriving the matters that the Department of State must take into consideration while preparing the report, directly from declarations provisions, one can also find other aims and goals that its signatories declare to fulfill, which are not mentioned later in the JUST Act. These are aims and goals such as: activities on identifying and restoration of Jewish burial grounds and cemeteries or organizing official state events commemorating Holocaust victims and also introducing and emphasizing the topics of Holocaust and Nazi war crimes in public education. ${ }^{11}$

Another fact that is crucial for the discussed matters is that one of the goals of the Terezin Declaration was establishing the European Shoah Legacy Institute, which, in accordance with declarations provisions, published eight reports on fulfilling the aims and goals of the declaration during the time of its activity which was between the years 2010-2017. As it was mentioned above, the reports covered an even broader range of states' activities than should be the matter of interest of the Department of State according to the JUST Act. ${ }^{12}$ Regarding that, one can find the opinions and statements that appeared in the Polish public debate on the JUST Act even more interesting.

\section{SEMIOLOGICAL APPROACH TO THE STUDIES OF POLITICAL MYTH AND THE TERM "JEWISH CLAIMS"}

One of the perspectives from which we can look at the mythical phenomenon created in the Polish public debate on the JUST Act is the one proposed by R. Barthes. In this context, no one should be surprised by the use of methodology which was originally used by the author to analyze mythical content rather in the elements of cultural and social reality than in the legal and political one. Even Barthes noticed that the subject of interest of those who study the myth may be very broad, while noticing that the myth is not determined by the object of its transmission, but by the form in which this transmission is expressed and that the limitations of the myth are only formal and never substantial. ${ }^{13}$

Barthes was analyzing myths as products of the semiological system, which is understood as a pattern of giving meaning to different words. In this process, a relation between the three elements: signifier, signified and the sign is assumed

${ }_{11}$ See Terezin Declaration of 30 June 2009, https://wjro.org.il/cms/assets/uploads/2019/06/ terezin_declaration.pdf [access: 27.01.2020].

${ }_{12}$ More information about the European Shoah Legacy Institute activities can be found on its website: www.shoahlegacy.org [access: 27.11.2019].

13 R. Barthes, op. cit., p. 25. 
(Figure 1). The signifier becomes a form, or in other words way of transmitting the meaning for the signified that is imbued with content. Those two elements combined together create a sign that can be read by the recipient. But it is what happens in the next step of the pattern that is for Barthes a crucial stage of creating the myth. Another step is built over the one described above. That following step transforms what was a final sign in the first one into a new signifier of the second step. As a result, the meaning that was embodied in the final sign of the first step is acquired by the second one and becomes a form of transmission for the mythical content, which in the end can be read by the recipient as the mythical signs. ${ }^{14}$

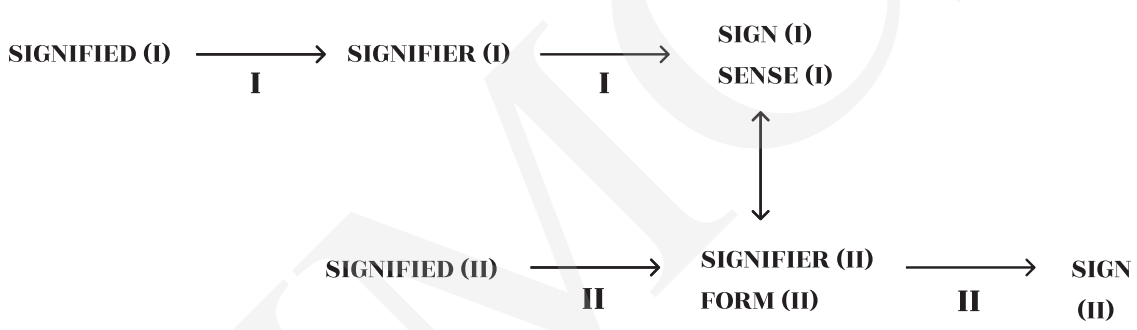

Figure 1. The semiological scheme of R. Barthes

Source: own elaboration.

For Barthes, the most important result of this process in which myth is formed is an effect that he calls regression. It is a situation in which a sign that is the final product of the second stage of the system, despite being structurally connected with the meaning assigned at the first stage, does not carry that meaning anymore. In this case, as the author notices, "a myth captures a completed sense and changes it into an empty, parasitic form". In this process "the sense loses all its meaning while still being alive and eaten by the mythical form". ${ }^{15}$

How those briefly presented theoretical tools can be used to describe discussions concerning the JUST Act? Well, they may turn out to be extremely useful when it comes to analyzing the term "Jewish claims" which is widely used by those who take the floor in the debate on the JUST Act. As an example, the mentioned term can be found in the article published by a website Polonia Christiana under the title: „Stop 447”. Czy narodowcy obronia Polskę przed roszczeniami? ("Stop 447”: Will the nationalists defend Poland form the claims?) by M. Wałach. ${ }^{16}$ In this case, the

${ }^{14}$ Ibidem, pp. 29-34.

15 Ibidem, pp. 35-36.

16 M. Wałach, ,Stop 447”. Czy narodowcy obronia Polske przed roszczeniami?, 8.11.2019, www.pch24.pl/stop-447--czy-narodowcy-obronia-polske-przed-roszczeniami-,72041,i.html [access: 27.01.2021]. 
term "claim" functions as a mythical sign, a product of the second stage of the semiological system. Furthermore, the author of the article allows the reader to directly watch the process of regression, as described by Barthes. At the beginning of the text, the (Jewish) claims ${ }^{17}$ appear in the context of heirless property. As a sign, the term is filled with a clear legal meaning that is understood as someone's cause of dementing the return of some belongings (in this case it would be property) or execution of someone's rights. Later the author of the article explains, and it is without any doubt a truthful explanation which is still set in the legal context, that "in the legal systems that are based on the Roman law, if any heirless property appears, it should be returned to the community - for example to the state from which its deceased owner came from". ${ }^{18}$ But in the following part of the article, the discussed term is used to attribute a different meaning to it, under the guise of continuing a strictly legal discussion.

Jewish property became an inconvenient matter in Polish collective memory of the wartime Poland history of the years between 1939 and 1945. As A. Leder, an author of the book Prześniona rewolucja (Slept through Revolution) notices, the Holocaust crimes done by Nazi Germany resulted in derivative and often not expected possibility of social and economic advancement. That happened through claiming the empty socio-economical space which included property, land, means of production and companies that were all abandoned by Jews. ${ }^{19}$ As a result, that unsaid and inconvenient transition must have created a myth about Jewish groups of interest that constantly try to reclaim the "post-Jewish" property that now belongs to the Poles by using any possible means. This myth of course was not created as a brand new part of collective memory. It was based on many previous mythical stories about Jewish people that were creatively adapted to the new situation. It also emphasizes the mythical idea of eternal Polishness of the things that had to be defended from the "Jewish claims". The more the people of Polish ethnicity are forced to defend "our Polish property" from the Jews, the more (regarding the logic of this mythical narrative) we have the historical, moral and even legal legitimacy to actually own it.

In the article by M. Wałach, one can then observe the use of mechanisms that allows the sign from the first stage to be filled with a brand new meaning, thanks to regression. "Claims" than at first function only as a legal term are later used in different contexts, which correspond with the mythical narrative about Polish-Jewish history that was explained above. Moreover, those contexts are going to be quite far from the rational, legal interpretation of the JUST Act and its consequences. The author of the article expects that passing the JUST Act as American law, which

${ }^{17}$ It is not always that the "Jewish" part of the term is directly expressed by its users. Despite that, almost every time when this term appears in the context of the debate on JUST Act, the Jewish nature of the "silent" claimant can be without any doubt derived from the context.

${ }^{18} \mathrm{M}$. Wałach, op. cit.

19 A. Leder, Prześniona rewolucja. Ćwiczenia z logiki historycznej, Warszawa 2014, pp. 89-95. 
only legal result would be a one-time report based on some of the provisions of a non-binding Terezin Declaration, may have "dangerous consequences". He describes them as a risk of "distributing property to Jewish organizations" and that "compensating those claims" can only be done through "transferring valuable real estate into Jewish hands". Here it can be seen how through regression legal instruments of compensating one's loss can become a mythical powerful tool in the hands of unknown Jewish organizations, which also uses some well-established antisemitic stereotypes that view the Jews as those who economically exploit the Poles.

In his article, M. Wałach refers to the publication by A. Stelmach, published on the same portal, entitled ,JUST Act” $i$ duch Bartoszewskiego. Co dalej z żydowskimi roszczeniami? (,JUST Act” and Bartoszewski's spirit: What's next for Jewish claims?). The headline was illustrated with a meaningful picture of a group of Hasidic Jews praying in front of the United States Congresses façade. ${ }^{20}$ It also ends with a conclusion that as a result of introducing the JUST Act "Jews are going to demand a compensation from the Republic of Poland that will be worth 300 billion dollars". The author not only does not explain any justification for those calculations, but also does not explain how possibly this consequence can be derived from the fact that a legal act such as the JUST Act became the law in the United States. She does not even elaborate on who would be the claimant in this case. No legal person or organization is mentioned, only a collective entity - the Jews.

Another example of transformed, mythical understanding of the term "Jewish claims" can be seen in the publicity of an Internet television the National Media (Pol. Media Narodowe). In the Internet broadcast entitled Roszczenia żydowskie. Antypolonizm Żydów w USA ma dluga tradycję (Jewish claims: The anti-Polonism of Jews in the USA has a long tradition) the author proposes a religious explanation for Jewish claims. There is no question of a desire to get rich, it is completely replaced by a religiously sanctioned anti-Polonism. The author explains (based on some other publications that are promoted in the National Media) that in the Talmud, "the house of the gentile is seen as a barn for the animals". He also says that "the American-Jewish propaganda" does not only refer to material claims based on civil law. It is believed by him, that the next steps are political and territorial claims, since in his opinion Jews even in the year 1918 "made attempts to diminish our borders" since they were reluctant to accepting Poland's independence. The conclusion of his story is that, as he says "the history repeats itself" and that Jews once again are trying to do the same by enforcing the JUST Act. ${ }^{21}$ According to

20 A. Stelmach, ,JUST Act” $i$ duch Bartoszewskiego. Co dalej z żydowskimi roszczeniami?, 15.02.2019, www.pch24.pl/just-act-i-duch-bartoszewskiego--co-dalej-z-zydowskimi-roszczeniami-,59810,i.html [access: 27.01.2021].

${ }^{21}$ See Roszczenia żydowskie. Antypolonizm żydów w USA ma dluga tradycję, www.youtube. $\mathrm{com} / \mathrm{watch}$ ? $=\mathrm{kGQRL} 3 \mathrm{UfF} 60$ [access: 1.12.2019]. 
the semiological system presented before, legal forms of compensations that are in fact mentioned in the JUST Act are a sign of stage number one, that through the process of regression are turned into second stage's sign known as "Jewish claims" that have little to do with their previous legal aspect.

\section{A FUNCTIONAL DESCRIPTION OF THE “STOP 447” INITIATIVE}

Another possible use of the studies on political myth to describe the reception of the JUST Act in Poland is to look from this perspective at a project of a legislative initiative that was called "Stop 447". A functional description of the phenomenon of myth, on which the following considerations are based, is contained in the concept of Swedish political philosopher E. Cassirer, whose remarks on political myth were included in his book The Myth of the State. Reference was also made to the achievements of the Polish researcher T. Biernat, who described his remarks extensively in the monograph Mit polityczny (The Political Myth).

It is very interesting to look at the "Stop 447" initiative from this perspective. The project of this legislative initiative was created as a result of the discussion about the impact of the JUST Act. It's author is a nationalist NGO Roty Marszu Niepodległości. A legislative committee created by this organization started to collect signatures under a project of this new law on 29 October 2018. The project's main goal is to prohibit "any activities that may lead to acceptance of the claims concerning heirless property, including negotiations, settlements, recognitions of claims or plaints regarding heirless property, mediation or paying any financial or material compensations". This project also proposes discontinuation of "all civil and administrative proceedings that may lead to settling of the claims that are in connection with any heirless property". It also enforces a prohibition of any executive proceedings in those cases. Violation of the projected law's provisions would result in serious penal consequences, in some cases even up to five years of imprisonment. ${ }^{22}$

From a dogmatic perspective, such a project can be considered surprising. Especially, if one has in mind the provisions included in the JUST Act and their lack of legal consequences for the Polish legal system (also regarding the non-binding nature of the Terezin Declaration). It seems that introducing such a law would be absolutely unnecessary since it does not change legal situation of the heirless property at all. Lack of the need for new regulations in this area, including the penal regulations, are even more highlighted by the fact, that because of the currently binding regulations of the hereditary law as well as the procedures in reprivatisation

${ }^{22}$ Projekt ustawy „Stop 447”, https://stop447.info/wp-content/uploads/2019/09/OIU-STOP447projekt-ustawy-vo.pdf [access: 3.12.2019]. 
proceedings such as administrative, civil or executive proceedings will never happen in the first place. ${ }^{23}$ Why then introduce penal provisions relating to situations that will not take place in the current state of law? The answer to this question can be found in the reflections on functional aspects of the political myth, which is no unknown to the historians of political myth.

For T. Biernat, a place where one can search for the presence of myths are especially the myth's expressions. The author understands them as an application of some preexisting mythical convention to particular elements of our culture. They can be not only the so-called direct expressions, i.e. political ideologies, but also their indirect forms, which are other cultural products. One could consider the "Stop 447" project to be one of those indirect myth's expressions. The author also introduced a division between those myths that are created spontaneously (usually as an affectively motivated reaction to situations that lack an understandable and easy logical explanation, as wars, natural disasters, economic crises, etc.) and those that are intentionally created. ${ }^{24}$ An initiative like "Stop 447" would then belong to the second group, as a mythical tool used by the nationalist political groups. If one examined the "Stop 447" project using the functional typology proposed by Biernat, one would then notice that it can be seen as an indirect and intentionally created mythical expression. Understanding that, unveils the fact that the intention of a discussed project may not be the change of the law. Thanks to campaigning on this legislative initiative, the organizing committee was granted a massively important way of instilling the mythical content that the project bears, in those who may support it. Since what they proposed was said to have only a strictly legal meaning, including severe penal law changes, those who may be the recipients of their legislative campaign may consider it a radical reaction for then a really serious problem of "Jewish claims" that, thanks to the project, can be seen as a real risk for many Poles. It is without a doubt an example of using myth as a way of creating a meaning, which in this case is precisely the meaning that those who invented the project wanted to create.

Similar remarks on the concept of an intentionally created myth can be found in the writings of E. Cassirer, who noticed that:

The new myths do not arise as an outcome of a wild imagination. They are carefully crafted products, created by cunning and skillful specialists. [...] since then myths can be produced in the same sense as one can produce any modern weapon such as a machine gun or a jet fighter. ${ }^{25}$

${ }^{23}$ About the nature of reprivatisation proceedings, see $€$. Bernatowicz, Reprywatyzacja na przykładzie gruntów warszawskich, Warszawa 2015; Reprywatyzacja w orzecznictwie sądów, ed. M. Pilch, Warszawa 2016; Postępowania reprywatyzacyjne, ed. K. Wiktor, Warszawa 2018; P. Kociubiński, Powojenne przekształcenia własnościowe w świetle konstytucji, Warszawa 2013; P. Borecki, Reprywatyzacja nieruchomości na rzecz gmin wyznaniowych żydowskich, „Państwo i Prawo” 2011, no. 6, pp. 61-73.

${ }^{24}$ T. Biernat, Mit polityczny, Warszawa 1989, pp. 111-163.

${ }^{25}$ E. Cassirer, op. cit., p. 313. 
Cassirer also introduced a concept of the so-called magical word that focuses on the function of the mythical expressions. It has a very different character than a word in the sense of semantics. It is not used to describe the reality that surrounds us, but to create and change that reality to achieve certain goals and to generate certain emotions. ${ }^{26}$ It is also a concept that can be used to interpret the reason for which the "Stop 447" project was created. Introducing severe penal sanctions is not a way of adjusting the law to reality. On the contrary, it is a way of creating a new reality, which is adjusted to the rules of the myth on which the project is based. Moreover, thanks to this mechanism the myth that was the source of this whole process is then legitimized by the "Stop 447" project itself. The meaning and the role of the magical word, despite the concept being borrowed from a completely different approach to the studies of the myth, is surprisingly similar to the role played in this context by the process of regression described by R. Barthes.

\section{CONCLUSIONS}

The examples of using theoretical tools taken from the theory of political myth to describe political and legal processes definitely show that this approach leads to interesting conclusions. One can of course find many more of them than only those that were presented in this paper. They can make a great object of further scientific research. They also show that the problem of political myth is definitely an interdisciplinary one and that there is a lot that can be done in this area by the historians of political and legal thought. Since that, this article can only be treated as an invitation to look for the political myth in those areas that we all considered to be free from the irrationality of the myth.

The unsuspected accuracy of analyzing legal phenomenon from the mythical perspective points out the fact that often remains unnoticed - the legal reality is not free from mythical elements and the mythical way of thinking. In accordance with assumptions that were made above, the law is not different from any other product of our culture and, therefore, it is not free from the myth. This observation creates an obligation to always question the value of any new regulations. Legal disputes, as this paper presented, are not always purely rational. When our analysis of law lacks any doubt in its rationality, it may result in not noticing those legal changes that carry a mythical content that replaced the legal one. The approach to the legislative projects presented here will surely allow to question their flaws more effectively, at the same time defending us from nihilistic attitude of creating the law that has some hidden purposes, other than the legal changes.

\footnotetext{
${ }^{26}$ Ibidem, pp. 313-314.
} 
On 29 July 2020, almost half a year after this paper was written, the United States Department of State published the JUST Act Report. Since it is a document that covers the legal situation in 46 countries, its analysis would require a much more extensive description than this short supplement. From the perspective of the mythical fear of "Jewish claims" a part that refers to the legal status of the heirless property in Poland needs to be presented:

Poland has not passed a law to address the significant amount of private property left heirless by the Holocaust. Instead, heirless property is governed by Polish inheritance law, which requires that such property be returned to the local municipality or national treasury. ${ }^{27}$

\section{REFERENCES}

\section{Literature}

Barthes R., Mit i znak, Warszawa 1970.

Bernatowicz Ł., Reprywatyzacja na przykładzie gruntów warszawskich, Warszawa 2015.

Biernat T., Mit polityczny, Warszawa 1989.

Borecki P., Reprywatyzacja nieruchomości na rzecz gmin wyznaniowych żydowskich, „Państwo i Prawo" 2011, no. 6.

Cassirer E., Mit państwa, Warszawa 2006.

Eliade M., Aspekty mitu, Warszawa 1998.

Eliade M., Mity, sny, misteria, Warszawa 1999.

Kociubiński P., Powojenne przekształcenia własnościowe w świetle konstytucji, Warszawa 2013.

Leder A., Prześniona rewolucja. Ćwiczenia z logiki historycznej, Warszawa 2014.

Napiórkowski M., Mitologia wspótczesna, Warszawa 2018.

Postępowania reprywatyzacyjne, ed. K. Wiktor, Warszawa 2018.

Reprywatyzacja w orzecznictwie sądów, ed. M. Pilch, Warszawa 2016.

\section{Netography}

European Shoah Legacy Institute, www.shoahlegacy.org [access: 27.11.2019].

Justice for Uncompensated Survivors Today (JUST) Act of 2017, www.congress.gov/115/plaws/ pub1171/PLAW-115pub1171.pdf [access: 27.01.2020].

Projekt ustawy „Stop 447”, https://stop447.info/wp-content/uploads/2019/09/OIU-STOP447-projekt -ustawy-vo.pdf [access: 3.12.2019].

Roszczenia żydowskie. Antypolonizm żydów w USA ma dhugą tradycję, www.youtube.com/watch?v=kGQRL3UfF6o [access: 1.12.2019].

${ }^{27}$ The JUST Act Report, www.state.gov/wp-content/uploads/2020/02/JUST-Act5.pdf [access: 11.01.2021]. 
Stelmach A., ,,JUST Act” i duch Bartoszewskiego. Co dalej z żydowskimi roszczeniami?, 15.02.2019, www.pch24.pl/just-act-i-duch-bartoszewskiego--co-dalej-z-zydowskimi-roszczeniami--,59810,i. html [access: 27.01.2021].

Terezin Declaration of 30 June 2009, https://wjro.org.il/cms/assets/uploads/2019/06/terezin_declaration.pdf [access: 27.01.2020].

The JUST Act Report, www.state.gov/wp-content/uploads/2020/02/JUST-Act5.pdf [access: 11.01.2021].

Wałach M., ,Stop 447”. Czy narodowcy obronia Polske przed roszczeniami?, 8.11.2019, www. pch24.pl/stop-447--czy-narodowcy-obronia-polske-przed-roszczeniami-,72041,i.html [access: 27.01.2021].

\begin{abstract}
ABSTRAKT
W artykule ukazano akt prawny jako potencjalny przedmiot mitologizacji. Do opisu fenomenu należącego ściśle do rzeczywistości polityczno-prawnej - amerykańskiej ustawy JUST, która w polskiej debacie publicznej wywołała w ostatnich latach liczne kontrowersje - użyto bowiem narzędzi wykorzystywanych w badaniach nad zjawiskiem mitu politycznego. Stosując osiągnięcia teoretyczne wybitnych badaczy mitu, takich jak R. Barthes czy E. Cassirer, wykazano, że akty prawne oraz ich recepcja i interpretacja nie zawsze opierają się na racjonalnych formach poznania. Może na nie wpływać także mit polityczny i mityczna forma poznania, co przedstawiono w niniejszym opracowaniu za pomocą znanych badaniom nad mitem narzędzi teoretycznych. W artykule sformułowano interesujące uwagi, które mogą być przydatne dla lepszego zrozumienia zjawisk z pogranicza polskiego prawoznawstwa, politologii i mitologii.
\end{abstract}

Slowa kluczowe: mit polityczny; akt prawny; ustawa JUST; mitologizacja 